Jurnal Ilmu Sosial dan Pendidikan (JISIP)

Vol. 6, No. 1 Januari 2022

e-ISSN : 2656-6753, p-ISSN: 2598-9944

DOI: 10.36312/jisip.v6i1.2740/http://ejournal.mandalanursa.org/index.php/JISIP/index

\title{
Fungsi Pengawasan Partisipatif Dalam Mewujudkan Pemilu Demokratis Tahun 2024
}

\author{
Isnanto Bidja \\ Dosen Fakultas Hukum, Universitas Tompotika Luwuk Banggai
}

\begin{tabular}{l}
\hline Article Info \\
\hline Article history: \\
Received 20 Desember 2021 \\
Publish 04 Januari 2022
\end{tabular}

Keywords:

Monitoring,

Participatory Monitoring,

Election,

Democratic

\section{Info Artikel}

\section{Article history:}

Diterima 20 Desember 2021

Publis 04 Januari 2022

\begin{abstract}
The involvement of the community in the political process is very necessary to be considered as the existence of political apathy in the general election. The political process can be said to be democratic when the community is the main actor in making political decisions, so that democracy guarantees the participation of the community itself. Participatory election supervision is a joint way of how the community can participate in supervising both campaigns, calm periods and election day by transforming moral strength into strength. with the consequence of having knowledge and skills about electoral and monitoring techniques. The main problem in this research is how to implement participatory supervision in realizing democratic elections?. The results show that participatory supervision plays a strategic role in the formation of responsive and impartial electoral law, implementation of election law by supervisors at the field level and the formation of a community legal culture/culture that can support the creation of participatory supervision for the realization of democratic elections in 2024.

ABSTRAK
Pelibatan masyarakat dalam proses politik sangat diperlukan untuk meredam adanya
apatisme politik masyarakat dalam pemilihan umum. Proses politik bias dikatakan
demokratis ketika masyarakat menjadi aktor utama dalam pembuatan keputusan
politik, sehingga pemilu yang demokratis mewajibkan partisipasi masyarakat itu
sendiri.pengawasan partisipatif adalah usaha bersama bagaimana masyarakat dapat
turut serta mengawasi pemilu baik dalam kampanye, masa tenang dan hari
pemilihan dengan upaya mentransformasikan kekuatan moral menjadi kekuatan
sosial dengan konsekuensi memiliki pengetahuan dan keterampilan tentang
kepemiluan dan teknik pengawasan. Permasalahan utama dalam penelitian ini
adalah bagaimanakah pelaksanaan pengawasan partisipatif dalam mewujudkan
pemilu yang demokratis ?. Hasil penelitian menunjukkan bahwa pengawasan
partisipatif memegang peranan yang strategis saat pembentukan hukum pemilu
yang responsif dan memihak pada masyarakat, pelaksanaan hukum pemilu oleh
pengawas ditingkat lapangan dan pembentukan kuktur/budaya hukum masyarakat
yang dapat menunjang terciptanya pengawasan partisipatif guna terwujudnya
pemilu yang demokratis Tahun 2024 .
\end{abstract}

This is an open access article under the Lisensi Creative Commons Atribusi-BerbagiSerupa 4.0 Internasiona

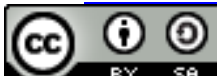

\section{Corresponding Author: \\ Isnanto Bidja}

Universitas Tompotika Luwuk Banggai

Email: isnantobidja@yahoo.co.id

\section{PENDAHULUAN}

Pemilihan umum yang selanjutnya disebut pemilu adalah sarana kedaulatan rakyat untuk memilih anggota Dewan Perwakilan Rakyat, Dewan Perwakilan Rakyat Daerah, Presiden dan Wakil Presiden, dan untuk memilih Anggota Dewan Perwakilan Daerah yang dilaksanakan secara 
langsung, umum, bebas, rahasia, jujur dan adil dalam Negara Kesatuan Republik Indonesia berdasarkan Pancasila dan Undang-Undang Dasar Negara Republik Indonesia Tahun 1945. Sehubungan dengan tujuan pelaksanaan Pemilu maka penyelenggara Pemilu harus mampu menjaga kualitas Pemilu yang ditunjukkan dengan hasil pemilu yang berintegriitas dan akuntabel. Namun pada kenyataannya pelanggaran dan kecurangan kerap terjadi pada setiap pelaksanaan Pemilu dengan berbagai bentuk dan setiap tahapannya. Pelanggaran Pemilu berdasarkan jenisnya dibagai menjadi 4 kategori, yaitu : a). pelanggaran administrasi, b). pelanggaran tindak pidana, c). pelanggaran kode etik oleh penyelenggara Pemilu (KPU, KPU Provinsi, KPU Kabupaten/Kota, Bawaslu, Bawaslu Provinsi, dan Bawaslu Kabupaten/Kota, dan d). pelanggaran peraturan perundang-undang lainnya.

Pelanggaran dan kecurangan Pemilu tentu harus diantisipasi dan mendapatkan penindakan, ini artinya pelaksanaan Pemilu harus diawasi. Dalam konteks pengawasan, Badan Pengawas Pemilihan Umum (selanjutnya disebutn Bawaslu) memegang peranan penting untuk mengontrol pelaksanaan Pemilu dalam kaitannya menjaga integritas dan akuntabilitas Pemilu. Pengawasann Pemilu dilakukan mengacu pada regulasi yang terkait dengan pelaksanaan Pemilu. Salah satu langkah antisipasi terjadinya pelanggaran dan kecurangan Pemilu oleh Bawaslu adalah pembuatan Indeks Kerawanan Pemilu (IKP) untuk memetakan potensi kerawanan yang disebabkan oleh pelanggaran dan kecurangan Pemilu. Berdasarkan pengalaman pelaksanaan pemilu-pemilu sebelumnya, Bawaslu telah berupaya untuk melakukan perbaikan-perbaikan dalam rangka melakukan kontrol terhadap pelaksanaan Pemilu yang tercermin dalam rencana strategis Bawaslu, yaitu :

a. Pembuatan dan peningkatan mutu regulasi pengawasan Pemilu

b. Peningkatan profesionalisme, spesialisasi, dan integritas struktur kelembagaan pengawas Pemilu

c. Peningkatan dukungan layanan administrasi, organisasi, dan manajemen

d. Peningkatan kapasitas dan kapabilitas personil pengawas Pemilu

e. Pengembangan pola dan metode pengawasan

f. Penguatan sistem kontrol nssional, dalam satu manajemen pengawasan yang bersifat terstruktur, sistematis, dan integratif berbasis teknologi

g. Peningkatan dukungan sarana dan prasarana

h. Kerjasama antar lembaga, dan

i. Peningkatan pelibatan masyarakat dalam pengawasan partisipatif.

Upaya perbaikan pengawasan Pemilu tentu harus mendapatkan dukungan baik oleh penyelenggara Pemilu lainnya (KPU dan DKPP), peserta Pemilu, dan masyarakat. Selain itu salah satu fokus Bawaslu terkait pengawasan Pemilu adalah tertuju pada pelibatan masyarakat untuk aktif ambil bagian menjadi pengawas Pemilu partisipatif. Bawaslu menganggap penting untuk mendorong pelibatan pengawasan Pemilu oleh masyarakat yang didasarkan pada kepedulian dan dalam konteks "serah terima kedaulatan" masyarakat itu sendiri yang dalam proses Pemilu. Pengawasan Pemilu partisipatif sendiri didasarkan pada pengertian partisipasi politik. Menurut Herbert McClosky, partisipasi politik adalah kegiatan-kegiatan sukarela dari warga masyarakat melalui mana mereka mengambil bagian dalam proses pemilihan penguasa secara langsung atau tidak langsung dalam proses pembuatan kebijakan umum (Rohaniah dan Efriza, 2021).

Pemilu sebagai sebagai salah satu sarana perwujudan demokrasi harus dilaksanakan secara demokratis. Setidaknya terdapat tiga syarat untuk menilai apakah Pemilu dilaksanakan secara demokratis atau tidak:

a. Ada atau tidaknya pengakuan dan perlindungan Hak Asasi Manusia (HAM)

Pemilu dapat dikatakan demokratis apabila pada saat pencalonan peserta pemilu memberikan peluang yang sama bagi setiap warga negara untuk mencalonkan dirinya sebagai peserta pemilihan umum, telah diatur secara tegas dalam peraturan perundang-undangan bahwa peserta Pemilu Presiden dan Wakil Presiden adalah perseorangan yang diusung oleh partai politik atau gabungan partai politik, peserta Pemilu DPR dan DPRD adalah parta politik, peserta Pemilu 
DPD peseorangan yang telah memenuhi persyaratan, dan peserta pemilihan kepala daerah adalah peseorangan yang berasal dari partai politik atau calon independen.

b. Terdapat persaingan yang adil diantara peserta Pemilu

Hal ini erat kaitannya dengan pelaksanaan Pemilu itu sendiri, pelaksanaan Pemilu yang demokratis tidaklah cukup jika hanya memberikan peluang yang sama bagi setiap warga negara untuk mencalonkan dirinya sebagai peserta Pemilu. Peluang yang sama dalam hal pencalonan tersebut haruslah juga dibarengi dengan peluang yang sama untuk kemudian menjadi pemenang dari Pemilu itu sendiri, itulah sebabnya mengapa pelaksanaan Pemilu yang demokratis tidaklah hanya berbicara mengenai pelaksanaan Pemilu itu dilakukan secara langsung ataupun melalui perwakilan, namun lebih kepada bagaimana setiap peserta Pemilu memiliki peluang yang sama untuk menjadi pemenang dalam pelaksanaan Pemilu.

c. Kepercayaan masyarakat atas hasil Pemilu

Kepercayaan masyarakat terhadap Pemilu sehingga menghasilkan pemerintahan yang legitimate akan dengan sendirinya terbangun jika tidak terdapat pelanggaran dan permasalahan terhadap hasil dari pelaksanaan Pemilu. Jika terdapat kesalahan dan pelanggaran-pelanggaran Pemilu dan perselisihan hasil Pemilu hal tersebut bisa diselesaikan secara demokratis dan proporsional melalui mekanisme hukum agar Pemilu tetap legitimate. Terkait hal ini Mahkamah Konstitusi hadir sebagai lembaga peradilan yang memiliki kewenangan untuk memutuskan dalam tingkat pertama dan terakhir yang putusannya bersifat final untuk memutus perselisihan tentang hasil pemilihan umum dan pemilihan kepala daerah sebagaimana termuat dalam Pasal 24C perubahan ketiga Undang-Undang Dasar Negara Republik Indonesia Tahun 1945 (Bidia, 2017).

Berdasarkan uraian dari latar belakang diatas , maka dapat dijadikan rumusan masalah adalah Bagaimanakah Fungsi Pengawasan Partisipatif Dalam Mewujudkan Pemilu Yang Demokratis Tahun 2024. Adapun tujuan dalam penelitian ini adalah untuk menjelaskan dan menganalisis Bagaimanakah Fungsi Pengawasan Partisipatif Dalam Mewujudkan Pemilu Yang Demokratis Tahun 2024.

\section{METODE PENELITIAN}

Berdasarkan sifat dan tipe penelitian, maka penelitian ini tergolong kedalam penelitian deskriptif yaitu penelitian yang memberikan gambaran tentang permasalahan hasil penelitian secara lengkap dan sistematis (Sumardjono, 1996). Pada prinsipnya penelitian ini adalah termasuk penelitian hukum normatif (legal research) yaitu penelitian yang dimaksud untuk mengkaji kaedah hukum dan azas hukum (Soemitro, 1990). Untuk memperoleh data dalam penelitian ini dilakukan dengan cara metode penelitian kepustakaan (library research) yaitu pengkajian terhadap peraturan perundang-undangan,literatur-literatur,dokumen-dokumen,tulisan-tulisan para ahli hukum dan tulisan yang erat kaitannya dengan penelitian ini, hal ini untuk memperoleh data primer,sekunder, dan tersier dan penelitian lapangan (filed research) sebagai penunjang untuk memperoleh data primer.

\section{HASIL PENELITIAN DAN PEMBAHASAN}

\section{Fungsi Pengawasan Partisipatif Dalam Mewujudkan Pemilu Demokratis Tahun 2024}

Dalam upaya mewujudkan Pemilu demokratis Tahun 2024 pengawasan yang melibatkan elemen masyarakat adalah sebuah prasyarat utama, tanpa dukungan keterlibatan seluruh masyarakat maka pengawasan akan sulit diwujudkan yang akan mempengaruhi terwujudnya Pemilu demkratis tahun 2024 nanti. Metode pengawasan Pemilu merupakan rangkaian kegiatan untuk memastikan apakah tahapan-tahapan Pemilu berjalan seusai apa yang telah ditetapkan. Kegiatan pengawasan Pemilu merujuk pada fungsi dibentuknya Badan Pengawas Pemilu yang tercermin melalui tugas dan kewajiban serta wewenangnya. Dalam melakukan pengawasan Pemilu bawaslu tidak hanya bekerja pada saat Pemilu terlaksana tetapi sejak mulai dari persiapan penyelenggaraan Pemilu. Terkait 
pelaksanaan pengawasan Pemilu maka diperlukan metode atau strategi bagaimana kegiatan pengawasan tersebut dilakukan.

Pengawasan partisipatif mengacu pada pemahaman tentang partisipasi politik. Partisipasi politik itu sendiri adalah bagaimana keterlibatan masyarakat atau rakyat banyak dalam kegiatankegiatan politik. Kegiatan-kegiatan politik dapat dibagai menjadi dua jenis : a). kegiatan-kegiatan politik yang bersifat menimbulkan gugatan/tuntutan terhadap sistem politik atau pemerintah, b). kegiatan-kegiatan politik yang berupa kegiatan mendukung gagasan-gagasan dan kebijakankebijakan yang dihasilkan oleh sistem pemerintah.

Dalam konteks pengawasan Pemilu partisipasi jelas bahwa masyarakat atau kelompok masyarakat terlibat dalam kegiatan politik. Masyarakat atau kelompok masyarakat yang terlibat didalamnya bisa mendukung maupun kemudian menjadi penggugat proses dan hasil Pemilu. Urgensi pengawasan partisipatif yang dilakukan masyarakat berfungsi untuk memperkuat kapasitas dan kualitas pengawasan, baik pilkada maupun Pemilu sehingga mendorong perluasan wilayah pengawasan. Dengan peningkatan jumlah penduduk, daerha pemilihan, dan jumlah kursi, seharusnya juga berimbang pada peningkatan partisipasi aktif masyarakat dalam melakukan pengawasan.

Pada prinsip pengawasan partisipatif yang digaungkan pengawas Pemilu adalah masyarakat tidak hanya berperan pada peningkatan persentase kehadiran saat pencoblosan saja, tetapi lebih mengarah pada pengawasan proses pemilihan sejak awal. Pengawasan Pemilu berupaya membangun sinergi dengan para tokoh stakeholder (tokok masyarakat, tokoh agama, tokoh pemuda, ormas, mahasiswa, dan pemilih pemula), termasuk mendorong kesadaran masyarakat untuk bersama mengawasi segenap proses yang ada minimal menjadi informan awal bagi pengawas Pemilu.

Salah satu tugas pencegahan pelanggaran dan sengketa Pemilu sebagaimana amanat UndangUndang Nomor 7 Tahun 2017 adalah meningkatkan partisipasi masyarakat dalam pengawasan Pemilu maka Bawaslu mewujudkannya dengan membentuk sebuah wadah pusat partisipasi masyarakat. Wujud pusat partisipasi masyarakat adalah :

a. Pengawasan berbasis teknologi informasi (Gowaslu)

Gowaslu adalah portal bersama yang dapat menghubungkan jajaran pengawas (yang memiliki kewenangan pengawasan dan menerima informasi awal dugaan pelanggaran) dengan metode yang dapat dengan mudah dan cepat dijangkau oleh pemantau dan masyarakat pemilih.

b. Pengelolaan media sosial

Pengelolaan media sosial adalah pengelolaan media sebagai media sosialisasi dan transfer pengetahuan danketerampilan pengawasan Pemilu dari pengawasa pemilu kepada masyarakat untuk mendorong pelibatan masyarakat dalam pengawasan Pemilu.

c. Forum warga pengawasan Pemilu

Forum warga sebagai salah satu model dalam peningkatan pengawasan partisipasi masyarakat untuk mengawal penyelenggaraan Pemilu adalah wujud pelaksanaan peraturan undang-undang. Melalui pendidikan pengawasan Pemilu diharapkan forum warga memiliki karakter sebagai pengawas Pemilu.

d. Gerakan pengawas pemilu partisipatif

Gerakan pengawas partisipatif Pemilu merupakan upaya untuk membangun kesadaran masyarakat tentang kepemiluan dan meningkatkan partisipasi politik dalam semua segmen pemilih. Mengorganisasi gerakan pengawas partisipatif dilakukan oleh Bawaslu dengan menyertakan semua stakeholders kepemiluan.

e. Pengabdian masyarakat dalam pengawasan Pemilu

Program pengabdian pada masyarakat merupakan salah satu bagian dari kurikulum mahasiswa program pendidikan S-1. Program ini bersifat wajib dilaksanakan oleh mahasiswa dengan berlandaskan pada prinsip-prinsip kompetensi akademik,jiwa kewirausahaan (enterpreneurship), dan prefesional sehingga dapat menghasilkan program pengabdian kepada 
masyarakat yang bermutu, relevan, dan sinergis dalam meningkatkan pemberdayaan masyarakat.

f. Pojok pengawasan

Pojok pengawasan adalah pusat pengembangan ilmu dan pengetahuan mengenai demokrasi dan pengawasan Pemilu. Manfaat tersebut bukan hanya diberikan bagi publik awam saja namun juga untuk penggiat dan pemantau Pemilu bagi para pemangku kepentingan Pemilu dan pengawasan Pemilu terutama bagi pengawas Pemilu itu sendiri.

g. Panduan saka adhyasta pemilu

Satuan Karya Pramuka Adhyasta Pemilu disingkat Saka Adhyasta Pemilu adalah satuan karya pramuka yang merupakan wadah kegiatan keadhyastaan (pengawalan) Pemilu untuk mengingkatkan pengetahuan dan keterampilan praktis dalm bidang pencegahan dan pengawasanpemilu guna menumbuhkan kesadaran berperan serta dalam pengawasan Pemilu

Pemetaan potensi rawan pelanggaran dilakukan dengan mengidentifikasi dan memetakan potensi rawan pelanggaran pada setiap tahapan Pemilu dan aspek-aspek penting lalinnya yang tidak termasuk tahapan Pemilu. Wilayah pengawasan dilakukan dengan mempertimbangkan tinggi rendahnya tingkat kerawanan dan besarnya potensi pelanggaran diwilayah tertentu berdasarkan pengalaman Pemilu sebelumnya.Tindakan pencegahan pada wilayah potensi rawan pelanggaran dilakukan dengan :

a. Tindak pencegahan dapat dilakukan melalui penguatan koordinasi antar lembaga seperti MoU Bawaslu dengan pihak-pihak terkait

b. Peningkatan transparansi dan akuntabilitas pelaksanaan Pemilu, melakukan sosialisasi ketempattempat yang tinggi potensi terjadinya pelanggaran Pemilu

c. Melakukan kegiatan-kegiatan lain yang tidak bertentangan dengan peraturan perundangundangan. Dengan hal tersebut berarti pengawas Pemilu sudah membuat rencana untuk fokus pengawasannya

d. Memperkuat koordinasi dan kerjasama antar lembaga, merupakan langkah penting untuk menyatukan persepsi bersama bahwa Pemilu yang bersih bebas pelanggaran merupakan kepentingan bersama dalam rangka memperkuat demokrasi di indonesia.

Pada tahap pra Pemilu pengawasan dilakukan pada tahapan :

a. Pemutakhiran data pemilih dan penyusunan daftar pemilih

b. Pendaftaran dan verifikasi peserta Pemilu

c. Penetapan peserta Pemilu

d. Penetapan jumlah kursi dan penetapan daerah pemilihan, pencalonan Presiden dan Wakil Presiden serta anggota DPR, DPD, DPRD Provinsi, dan DPRD Kabupaten/Kota

e. Masa kampayen Pemilu

Pada tahap pelaksanaan Pemilu titik fokus pengawasan dilakukan pada daerah tahapan Pemilu yang rawan terjadi pelanggaran saat pesta demokrasi berlangsung. Tahapan rawan adalah saat kampanye dan pungut hitung suara. Selanjutnya pengawasan dilakukan setelah Pemilu, artinya pengawasan dilakukan untuk evaluasi dan pengembangan juga dapat mengawasi terjadinya sengketa perolehan suara.setelah dilakukan pengawasan dengan berbagai cara mekanisme pencegahan pelanggaran Pemilu, bawaslu juga memiliki wewenang untuk menindaklanjuti temuan dan laporan dugaan pelanggaran Pemilu yang diatur dalam Perbawaslu Nomor 13 Tahun 2017 Tentang Fokus Penindakan. Ketika temuan dan laporan dugaan Pemilu sudah ditindaklanjuti maka pengawas pemilu menyampaikan temuan atau laporan dugaan pelanggaran kepad pihak atau instansi yang berwenang.

Pengawasan yang baik dalam suatu sistem Pemilu adalah syarat utama dalam mewujudkan sistem demokrasi, yang hakikat demokrasi sebagai suatu sistem bermasyarakat dan bernegara serta pemerintahan memberikan penekanan pada keberadaan kekuasaan di tangan rakyat baik dalam penyelenggaraan berada ditangan rakyat mengandung pengertian tiga hal, yaitu : 
a. Pemerintahan dari rakyat (government of the people)

Mengandung pengertian yang berhubungan dengan pemerintahan yang sah dan diakaui (legitimate government) dimata rakyat. Sebaliknya ada permintaan yang tidak sah dan tidak diakui (unlegitimate government). Pemerintahan yang diakui adalah pemerintahan yang mendapat pengakuan dan dukungan rakyat. Pentingya legitimasi bagi suatu pemerintahan adalah pemerintah dapat menjalankan roda birokrasi dan program-programnya.

b. Pemerintahan oleh rakyat (government by the people)

Pemerintahan oleh rakyat berarti bahwa suatu pemerintahan menjalankan kekuasaan atas nama rakyat bukan atas dorongan sendiri. Pengawasan yang dilakukan oleh rakyta dapat dilakukan secara langsung oleh rakyat maupun tidak langsung oleh rakyat / melaui DPR

c. Pemerintahan untuk rakyat (government for the people)

Mengandung pengertian bahwa kekuasaan yang diberikan oleh rakyat kepada pemerintah dijalankan untuk kepentingan rakyat. Pemerintah diharuskan menjamin adanya kebebasan seluas-luasnya.

Konsepsi demokrasi memberikan landasan dan mekanisme kekuasaan berdasarkan prinsip persamaan dan kesederajatan manusia demokrasi menempatkan manusia sebagai pemilik kedaulatan yang kemudian dikenal dengan prinsip kedaulatan rakyat. Kekuasaan yang diperoleh melalui mekanisme demokrasi, manakala konsepsi demokrasi menempatkan manusia sebagai pemilik kedaulatan yang kemudian dikenal dengan prinsip kedaulatan rakyat maka bisa dipastikan akan menjadi kekuasaan yang demokratis karena kehendak rakyatlah sebagai landasan legitimasinya (Asshiddiqie, 2005).

Suatu pemerintahan dinilai demokratis apabila dalam mekanisme dalam mekanisme pemerintahannya diwujudkan prinsip-prinsip demokrasi yang prinsip-prinsip tersebut berlaku universal, bahwa keberhasikan suatu negara dalam menerapkan demokrasi dapat diukur berdasarkan prinsip-prinsip tertentu, tolak ukur tersebut juga dapat digunakan untuk menilai keberhasilan pelaksanaan demokrasi pada suatu negara. Menurtu Inu Kencana Syafiiie prinsip-prinsip demokrasi yang berlaku universal antara lain :

a. Adanya pembagian kekuasaan

Pembagian kekuasaan dalam negara berdasarkan prinsip demokrasi dapat mengacu pada pendapat John Locke mengenai tria politica. Kekuasaan negara terbagi menjadi 3 bagian, yaitu eksekutif, legislatif dan yudikatif. Ketiga lembaga tersebut memiliki kesejajaran sehingga tidak dapat saling menguasai hanya dalam bingkai check and balences

b. Pemilihan umum yang bebas

Kedaulatan tertinggi dalam negara dmokratis berada ditangan rakyat,namun kedaulatan tersebut tidak dapat dilaksanakan secara langsung oleh setiap individu. Kedaulatan tersebut menjadi aspirasi seluruh rakyat melalui wakil-wakil rakyat dalam lembaga legislatif. Untuk menentukan wakil rakyat dilakukan pemilihan umum. Dalam pelaksanaannya setiap warga negara memiliki kebebasan untuk memilih wakil yang dikehendaki. Tidak dibenarkan adanya pemaksaan pilihan dalam negara demokrasi. Selain memilih wakil rakyat pemilihan umum juga dilakukan untuk memilih Presiden dan Wakil Presiden, DPD, DPRD dimana rakyat memiliki kebebasan sendiri dalam memilih pemimpinnya.

c. Peradilan yang bebas

Melalui pembagian kekuasaan lembaga yudikatif memiliki kebebasan dalam menjalankan perannya. Lembaga ini tidak dapat dipengaruhi lembaga negara yang lain. Dalam praktik kenegaraan hukum berada pada kedudukan tertinggi, semua yang bersalah dihadapan hukum harus mempertanggungjawabkan kesalahannya

d. Partai Politik

Partai politik menjadi wadah bagi warga negara untuk menyalurkan aspirasi politiknya. Setiap warga negara memiliki kebebasan untuk memilih partai politik yang sesuai hati 
nuraninya, sehingga sejak bergulirnya reformasi negara memberikan kebebasan bagi semua warga negara untuk mendirikan partai politik. Pada tahun 1999 dilaksanakan Pemilu multi partai pertama sejak orde baru. Mulai Pemilu Tahun 1999 setiap partai politik memiliki asas sesuai dengan perjuangan politik masing-masing. Tidak lagi dikenal asas tunggal bagi setiap partai politik. Namun pendirian partai politik harus sesuai dengan peraturan yang ada. Selain itu, warga negara tidak diperbolehkan mendirikan partai dengan asas maupun yang dilarang oleh undangundang

e. Pers yang bebas

Dalam sebuah negara demokrasi, kehidupan dan kebebasan pers harus dijamin oleh negara. Pers harus bebas menyuarakan hati nuraninya terhadap pemerintah maupun diri seorang pejabat.

f. Kebebasan individu

Dalam demokrasi negara harus menjamin kebebasan warga negara dalam berbagai bidang,misalnya kebebasan mengungkapkan pendapat, kebabasan berusaha, dan sebagainya, namun kebebasan itu harus dilakukan dengan bertanggungjawab. Perlu diingat bahwa kebebasan satu orang akan dibatasi oleh kebebasan orang lain. Dengan demikian, setiap masyarakat dapat melakukan kebebasan yang dijamin undang-undang dengan tidak merugikan kepentingan orang lain (Mahfud, 1999).

Pengawasan yang berkualitas dengan melibatkan masyarakat memang menjadi faktor utama dalam mewujudkan Pemilu yang berkualitas. Mewujudkan Pemilu yang demokratis bukanlah perkara sederhana, dibutuhkan tidak saja seperangkat instrumen regulasi yang tepat agar dapat mendukung terselenggaranya Pemilu demokratis, namun perilaku peserta dan penyelenggara Pemilupun juga merupakan hal tidak kalah penting dalam mewujudkan Pemilu yang demokratis, sampai saat ini kedua hal tersbut belum dapat mendukung terwujudnya Pemilu yang demokratis. Dari aspek regulasi melalui Undang-Undang Nomor 7 Tahun 2017 Tentang Pemilu telah disepakati Presidential Treshold sebesar 20 - $25 \%$ yang praktis membuat kontestasi Pemilu hanya dapat diikuti oleh parpol atau gabungan parpol yang mencapai angka tersebut. Jika kita tarik kembali pada ukuran Pemilu yang demokratis tentu hal ini menjadi satu permasalahan dalam mewujudkan Pemilu yang demokratis. Selian itu dari aspek regulasi juga munculnya ambang batas maksimal yang harus depenuhi oleh peserta pemilihan kepala daerah yang ingin mengajukan sengketa pilkada ke Mahkamaha Konstitusi, hal ini juga praktis membuat Mahkamah Konstitusi kembali ke paradigma mahkamah yang hanya mengedepankan angkaangka atua hanya mengedepankan keadilan prosedural dibandingkan mencari keadilan substantif.

\section{KESIMPULAN}

Mendasari rumusan masalah dan hasil penelitian tersebut, kesimpulan dari penelitian ini adalah bahwa pengawasan partisipatif memegang peranan yang strategis saat pembentukan hukum pemilu yang responsif dan memihak pada masyarakat, pelaksanaan hukum pemilu oleh pengawas ditingkat lapangan dan pembentukan kuktur/budaya hukum masyarakat yang dapat menunjang terciptanya pengawasan partisipatif guna terwujudnya pemilu yang demokratis Tahun 2024.

Mendasari rumusan masalah dan kesimpulan dalam penelitian ini maka dapat disarankan sebagai berikut:

a. Bagi pemerintah untuk dapat membentuk peraturan perundang-undangan dibidang hukum pemilu yang responsif, serta dapat segera membentuk peraturan pelaksanaannya sebagai dasar pembentukan peraturan teknis pengawasan partisipatif.

b. Bagi penyelenggaran untuk dapat membuka kesempatan bagi stakeholder untuk terlibat dalam pengawasan partisipatif. 


\section{DAFTAR PUSTAKA}

Isnanto Bidja, Politik Hukum Pengisian Jabatan Kepala Daerah (Menuju Penguatan Demokrasi Ditingkat Lokal ), Makassar, 2017.

Jimly Asshiddiqie, Demokrasi Dan Hak Asasi Manusia, Makalah Materi Yang Diberikan Dalam Stadium General pada acara The 1 National Conference Forum Community Development, Jakarta, 19 Desember 2005.

Mahfud MD, Hukum dan Pilar-Pilar Demokrasi , Gama Media Yogyakarta,2012

Perbawaslu Nomor 15 Tahun 2015 Tentang Rencana Strategis Badan Pengawas Pemilu Tahun 2015-2019

Rohaniah, Yoyoh dan Efriza, Sistem Politik Indonesia, Jakarta, Intrans Publishing, 2007, Hal. 272. Dalam Modul Sekolah Kader Pengawasan Partisipatif Tingkat Menengah 2021, Hal 5-6.

Ronny Hanitijo Soemitro, Metode Penelitian Hukum dan Jurimetri,Ghalia Indonesia, Jakarta, 2020

Sumardjono, M.S.W, Pedoman Pembuatan Usulan Penelitian, Sebuah Panduan Dasar, Gramedia Pustaka Utama, Jakarta 2016. 